\title{
Omeprazole induces altered bile acid metabolism
}

\author{
K Shindo, M Machida, M Fukumura, K Koide, R Yamazaki
}

\begin{abstract}
Background-It has been reported that the acidity of gastric contents could be an important factor in regulating jejunal flora.

Aims-To investigate the effects of omeprazole induced changes in gastric $\mathrm{pH}$ on jejunal flora and bile acid metabolism.

Methods-Twenty one patients with gastric ulcer and 19 healthy volunteers were studied. Deconjugation of bile acids was detected using a bile acid breath test. Jejunal fluid was aspirated using a double lumen tube with a rubber cover on the tip and deconjugation was examined using thin layer chromatography. Fat malabsorption was detected by a triolein breath test.
\end{abstract}

Results-In the bile acid breath test, expired breath samples from all patients and healthy volunteers showed significantly greater ${ }^{14} \mathrm{CO}_{2}$ specific activity after omeprazole treatment $(20 \mathrm{mg} / \mathrm{day})$ than before treatment. Bacterial overgrowth was found in the jejunal fluid and gastric juice of both ulcer patients and healthy volunteers after omeprazole treatment. The following species were identified: Escherichia coli, Candida albicans, enterococcus, Lactobacillus bifidus, Bacteroides vulgatus, B uniformis, Eubacterium lentum, Eu parvum, and Corynebacterium granulosum. All of these species, except $E$ coli and $C$ albicans, deconjugate bile acids. There was a significant correlation between ${ }^{14} \mathrm{CO}_{2}$ activity and gastric $\mathrm{pH}$, both before and after omeprazole treatment in both groups. The triolein breath test revealed impaired fat absorption in both groups after omeprazole treatment. Conclusions-Both patients with gastric ulcer and healthy volunteers exhibited increased deconjugation of bile acids caused by bacterial overgrowth in the jejunum and fat malabsorption after omeprazole treatment. The bacterial overgrowth consisted of both anaerobes and aerobes with deconjugation ability and was probably associated with an omeprazole induced shift to neutral $\mathrm{pH}$ in the gastric juice.

(Gut 1998;42:266-271)

Keywords: omeprazole; bacterial overgrowth; deconjugation; bile acid breath test; gastric $\mathrm{pH}$; gastric ulcer

The reduction of gastric acidity by antacids, ${ }^{1-3}$ $\mathrm{H}_{2}$ receptor antagonists, ${ }^{145}$ and omeprazole - a substituted benzimidazole that is a potent proton pump inhibitor ${ }^{6-8}$ - has been reported to increase gastric bacterial colonisation. Decreased gastric acidity due to atrophic gastritis is a common cause of reduced gastric secretion, resulting in overgrowth of gastric flora. ${ }^{9} 10$ Omeprazole potently inhibits gastric acid secretion by altering the activity of $\mathrm{H}^{+} / \mathrm{K}^{+}$ adenosine triphosphatase ${ }^{7}$ and reduces intragastric acidity more effectively than $\mathrm{H}_{2}$ receptor antagonists. ${ }^{11}$ This decrease in gastric acid secretion with omeprazole is long lasting. ${ }^{12-14}$ Thus, omeprazole may also increase bacterial colonisation in the jejunum, by altering jejunal $\mathrm{pH}$ due to gastric hypochlorhydria. The clinical consequences of omeprazole induced bacterial overgrowth in the jejunum are not however clear.

We formulated the following hypothesis: increased bile acid deconjugation in the jejunum of patients receiving omeprazole occurs due to bacterial overgrowth in the jejunum, induced by gastric hypochlorhydria.

To test this hypothesis, we determined whether: (1) patients with gastric ulcer and healthy volunteers who have received omeprazole exhibit positive bile acid breath tests due to bacterial overgrowth in the jejunum; (2) the bacteria in the jejunum are capable of deconjugation; (3) the deconjugation of glycine $-1-{ }^{14} \mathrm{C}$ labelled glycocholate is related to the change in gastric $\mathrm{pH}$ induced by omeprazole; and (4) subjects with a positive bile acid breath test exhibit fat malabsorption.

\section{Materials and methods}

Breath tests and bacterial studies were performed in 21 patients with gastric ulcer and 19 healthy volunteers at the First Department of Internal Medicine, Yokohama City University School of Medicine. The study was approved by the Ethical Committee of Yokohama City University School of Medicine. Written informed consent was obtained from each subject.

\section{STUDY SUBJECTS}

The study involved 21 male patients with gastric ulcer (group 1) and 19 healthy male volunteers (group 2) who were treated with oral omeprazole $20 \mathrm{mg}$ daily before breakfast for five weeks. The healthy volunteers (aged 24-75 years) were not taking other medication at the time of the study. The patients (aged 27-71 years) were allowed (but not encouraged) to take antacids in addition to omeprazole. Patients with benign gastric ulcer at the time of routine endoscopy were included; those who were considered suitable for medical treatment were given omeprazole and the importance of strict compliance with the treatment regimen was emphasised.

Following diagnosis by endoscopy, an initial ${ }^{14} \mathrm{C}$ glycocholic acid breath test (glycine test) 
and ${ }^{14} \mathrm{C}$ triolein breath test (triolein test) were performed, jejunal fluid and gastric juice were sampled by a double lumen tube,$^{15}$ and gastric $\mathrm{pH}$ was checked before omeprazole treatment. The usual dose of oral omeprazole $(20 \mathrm{mg} /$ day before breakfast) was given for five weeks. The same tests were performed in the healthy volunteers after endoscopy confirmed that there were no abnormal gastric findings.

The second glycine and triolein tests were performed in each subject in both groups after treatment with omeprazole for two weeks. Jejunal fluid and gastric juice were sampled using a double lumen tube, and the gastric $\mathrm{pH}$ was measured for the next two weeks during omeprazole treatment. Subjects with a positive glycine test underwent a third set of glycine and triolein tests after receiving oral tetracyline $1 \mathrm{~g} /$ day in divided doses for seven days during the 35 day course of omeprazole treatment. Generally, the triolein test was performed the day after the glycine test.

${ }^{14} \mathrm{C}$ GLYCOCHOLIC ACID BREATH TEST

Details of this procedure have been described previously. ${ }^{16}{ }^{17}$

${ }^{14}$ C TRIOLEIN BREATH TEST

After an overnight fast, ${ }^{14} \mathrm{C}$ labelled triolein (5 $\mu \mathrm{Ci}$ ), dissolved in $30 \mathrm{ml}$ of a high energy dietary supplement (Lipomul), ${ }^{18}$ was administered between 06.00 and 08.00 hours following each ${ }^{14} \mathrm{C}$ glycocholic acid breath test. The subjects remained at rest throughout the six hour study period during which hourly breath samples were taken; expired ${ }^{14} \mathrm{CO}_{2}$ was collected and measured, as noted earlier. Results are expressed as six hour cumulative ${ }^{14} \mathrm{CO}_{2}$ output as a percentage of the ingested activity. ${ }^{19-21}$

BACTERIAL CULTURES AND DECONJUGATION CAPABILITY

Jejunal fluid and gastric juice were aspirated through a double lumen tube with a rubber cover on the tip. ${ }^{15}$ This tube was positioned fluoroscopically at $30 \mathrm{~cm}$ past the ligament of Treitz in fasting subjects. The rubber cover was forced off by the instillation of saline just before the aspiration of jejunal fluid. Gastric juice was obtained by suctioning via the other lumen. Bacteria were cultured using the conventional plate method. All isolated anaerobes and aerobes were identified according to standard methods. $^{22} 23$ Jejunal and gastric colonisation were defined as more than $10^{5}$ bacteria per 0.5 $\mathrm{ml}$ of aspirate. Bacteria normally present in the small intestine (such as lactobacilli and streptococci) were also included in the colony counts. A loopful of bacteria from the plate cultures was inoculated into $10 \mathrm{ml}$ of broth that contained $0.5 \mathrm{ml}$ of sterilised ox gall instead of synthetic conjugated bile acid. Anaerobes were grown in thioglycolate liquid medium while the aerobes were grown in glucose medium. Incubation was performed at $37^{\circ} \mathrm{C}$ for 48 hours. The broth was acidified to $\mathrm{pH} 1.0$ with hydrochloric acid and extracted three times with two volumes of butanol. The three butanol phases were mixed, washed free of hydrochloric acid, and evaporated to dryness. Residues were dissolved in $2 \mathrm{ml}$ methanol, and $4 \mu \mathrm{l}$ aliquots were used for thin layer chromatographic analysis. Identification of free and conjugated bile acids was performed by thin layer chromatography, as previously reported. ${ }^{24} 25$

GASTRIC $\mathrm{pH}$

The gastric $\mathrm{pH}$ was measured in the morning after a 12 hour fast with all subjects in the supine position, using a glass electrode and a digital pH meter (Shimazu Co. Ltd, Kyoto, Japan). Normoacidity was defined as a $\mathrm{pH}$ between 1.5 and 2.0, hyperacidity as a $\mathrm{pH}$ less than 1.5 , hypoacidity as a $\mathrm{pH}$ between 2.4 and 4.0 , and anacidity as a $\mathrm{pH}$ greater than 4.0.

MATERIALS

Glycine- $1-{ }^{14} \mathrm{C}$ labelled glycocholate and ${ }^{14} \mathrm{C}$ labelled triolein (specific radioactivity of both, $0.25 \mu \mathrm{Ci} / \mathrm{mmol}$ ) were purchased from New England Nuclear Corp. (Boston, Massachusetts, USA). Lipomul meals were purchased from Upjohn Co. (Kalamazoo, Michigan, USA). The trapping solution for exhaled $\mathrm{CO}_{2}$ $(0.50 \mathrm{mmol} / \mathrm{ml})$ was prepared using equal amounts of $1 \mathrm{M}$ hyamine hydroxide (Packard Instruments Corp., Downers Grove, Illinois, USA) and absolute ethanol (containing 60 $\mathrm{mg} / \mathrm{l}$ of phenolphthalein as an indicator).

\section{STATISTICAL ANALYSIS}

Data are expressed as mean (SD) and as median (range). Logarithmic transformation of the $\mathrm{AUC}_{0-6}$ was used for statistical analysis. Paired and unpaired Student's $t$ tests were used for statistical comparisons of data conforming to normal distributions. Correlations between variables were determined using linear regression. Differences were considered statistically significant at a level of $\mathrm{p}<0.05$.

\section{Results}

${ }^{14} \mathrm{C}$ GLYCOCHOLIC ACID BREATH TEST

In group 1, the mean cumulative specific activity (percentage administered dose $/ \mathrm{mmol} \mathrm{CO}_{2} / 6$ $\left.\mathrm{h} ; \mathrm{AUC}_{0-6}\right)$ was $2.05(0.88) \times 10^{-3}$ and the mean total exhaled ${ }^{14} \mathrm{CO}_{2}$ was $1.49(0.40) \%$ of the administered dose, before omeprazole treatment. These values were $9.74(5.40) \times 10^{-3}$ and $5.34(2.87) \%$, respectively, after omeprazole treatment. There were significant differences in both parameters before and after omeprazole treatment $(\mathrm{p}<0.05$, paired $t$ test $)$

All 17 patients who received oral tetracycline for seven days exhibited flat curves. The mean cumulative specific activity in this group was $1.65(0.34) \times 10^{-3}$, and the mean total exhaled ${ }^{14} \mathrm{CO}_{2}$ was $1.27(0.27) \%$. Before the administration of tetracycline, these values were 10.71 $(5.48) \times 10^{-3}$ and $5.79(2.96) \%$, respectively, in this group. Thus, these parameters were significantly reduced by tetracycline.

In group 2, the mean cumulative specific activity was $2.53(0.97) \times 10^{-3}$ and the mean total exhaled ${ }^{14} \mathrm{CO}_{2}$ was $1.99(0.58) \%$ of the administered dose, before omeprazole treatment. These values were $9.71(5.71) \times 10^{-3}$ and $5.58(2.79) \%$ after omeprazole treatment. There were significant differences in both 
Table 1 fejunal bacterial flora in patients with gastric ulcer (group 1) and healthy volunteers (group 2)

\begin{tabular}{|c|c|c|c|}
\hline & \multicolumn{3}{|c|}{ Bacterial colonisation $\left(>10^{5} / 0.5 \mathrm{ml}\right)$} \\
\hline & $\begin{array}{l}\text { Before } \\
\text { omeprazole }\end{array}$ & $\begin{array}{l}\text { After } \\
\text { omeprazole }\end{array}$ & $\begin{array}{l}\text { After } \\
\text { tetracycline }\end{array}$ \\
\hline \multicolumn{4}{|c|}{ Group 1} \\
\hline 1 & E coli & $L$ bifidus & - \\
\hline 2 & - & - & - \\
\hline 3 & - & $C$ granulosum & - \\
\hline 4 & _- & Enterococcus & \\
\hline 5 & - & Eu parvum & - \\
\hline 6 & - & - & \\
\hline 7 & E coli & - & \\
\hline 8 & - & $B$ vulgatus & - \\
\hline 9 & - & - & E coli \\
\hline 10 & - & $L$ bifidus & - \\
\hline 11 & - & $B$ vulgatus & - \\
\hline 12 & _- & $B$ vulgatus & \\
\hline 13 & - & $B$ vulgatus & - \\
\hline 14 & _- & - & \\
\hline 15 & - & Enterococcus & \\
\hline 16 & - & - & \\
\hline 17 & - & C granulosum & - \\
\hline 18 & - & - & \\
\hline 19 & _- & - & $C$ albicans \\
\hline 20 & - & - & - \\
\hline 21 & E coli & Enterococcus & - \\
\hline \multicolumn{4}{|c|}{ Group 2} \\
\hline 1 & - & $B$ vulgatus & - \\
\hline 2 & _- & Eu parvum & \\
\hline 3 & - & $B$ vulgatus & - \\
\hline 4 & - & - & \\
\hline 5 & - & $L$ bifidus & - \\
\hline 6 & - & - & \\
\hline 7 & E coli & - & \\
\hline 8 & - & $B$ vulgatus & - \\
\hline 9 & E coli & Eu parvum & - \\
\hline 10 & - & - & - \\
\hline 11 & - & - & - \\
\hline 12 & - & - & \\
\hline 13 & - & $B$ vulgatus & \\
\hline 14 & - & $L$ bifidus & - \\
\hline 15 & - & EU lentum & - \\
\hline 16 & - & - & \\
\hline 17 & - & - & \\
\hline 18 & - & $B$ uniformis & E coli \\
\hline 19 & - & $C$ granulosum & - \\
\hline
\end{tabular}

-, No bacterial colonisation $>10^{5} / 0.5 \mathrm{ml}$ aspirate.

parameters before and after omeprazole treatment ( $\mathrm{p}<0.05$, paired $t$ test).

All 12 subjects who received oral tetracycline for seven days exhibited flat curves. The mean cumulative specific activity in this group was $1.71(0.33) \times 10^{-3}$, and the mean total exhaled ${ }^{14} \mathrm{CO}_{2}$ was $1.20(0.17) \%$. Before administration of tetracycline, these values were 11.44 (6.61) $\times 10^{-3}$ and $6.50(3.18) \%$, respectively, in this group. Thus, these parameters were significantly reduced by tetracycline.

BACTERIAL CULTURES AND DECONJUGATION CAPABILITY

Fejunal flora-As shown in table 1, in group 1, 19 of the 21 patients showed no growth before omeprazole treatment. The remaining two patients showed colonisation (more than $10^{5}$ colonies $/ 0.5 \mathrm{ml}$ ) with Escherichia coli. After omeprazole treatment, however, 12 patients had colonisation and nine showed no growth. After tetracycline treatment, 11 of the 13 patients tested showed no growth. The remaining two showed colonisation with $E$ coli and Candida albicans. In group 2, 16 of the 19 subjects showed no growth before omeprazole treatment. The remaining three subjects had colonisation (more than $10^{5}$ colonies $/ 0.5 \mathrm{ml}$ ) with $E$ coli. After omeprazole treatment, 11 subjects had colonisation and eight showed no growth. After tetracycline treatment, 10 of the 11 subjects tested showed no growth. The remaining subject showed colonisation with $E$ coli.

Gastric flora-As shown in table 2, in group 1,20 of the 21 patients showed no growth before omeprazole treatment. The remaining patient showed colonisation with $E$ coli. After omeprazole treatment however, 11 patients had colonisation and 10 showed no growth. After tetracycline treatment, 11 of the 13 patients tested showed no growth. The remaining two subjects showed colonisation with $E$ coli and $C$ albicans. In group 2, 17 of the 19 subjects showed no growth before omeprazole treatment. The remaining two subjects had colonisation with $E$ coli. After omeprazole treatment, nine subjects had colonisation and 10 showed no growth. After tetracycline treatment, eight of the 11 subjects tested showed no growth. The remaining three showed colonisation with $E$ coli and $C$ albicans.

Thin layer chromatography findings showed that isolated $E$ coli and $C$ albicans did not deconjugate ox gall. ${ }^{15}$ The other isolated species (enterococcus, Lactobacillus bifidus, Bacteroides vulgatus, B uniformis, Eubacterium parvum, Eu lentum, and Corynebacterium granulosum) however, were able to deconjugate ox gall.

Table 2 Gastric bacterial flora in patients with gastric ulcer (group 1) and healthy volunteers (group 2)

\begin{tabular}{|c|c|c|c|}
\hline & \multicolumn{3}{|c|}{ Bacterial colonisation $\left(>10^{5} / 0.5 \mathrm{ml}\right)$} \\
\hline & $\begin{array}{l}\text { Before } \\
\text { omeprazole }\end{array}$ & $\begin{array}{l}\text { After } \\
\text { omeprazole }\end{array}$ & $\begin{array}{l}\text { After } \\
\text { tetracycline }\end{array}$ \\
\hline \multicolumn{4}{|c|}{ Group 1} \\
\hline 1 & - & E coli & - \\
\hline 2 & - & Enterococcus & - \\
\hline 3 & - & Enterococcus & - \\
\hline 4 & - & Calbicans & \\
\hline 5 & - & C albicans & - \\
\hline 6 & - & - & \\
\hline 7 & - & - & \\
\hline 8 & - & L bifidus & - \\
\hline 9 & - & C albicans & - \\
\hline 10 & - & - & - \\
\hline 11 & - & - & - \\
\hline 12 & - & Enterococcus & \\
\hline 13 & - & C albicans & Calbicans \\
\hline 14 & - & - & \\
\hline 15 & - & - & \\
\hline 16 & - & - & \\
\hline 17 & - & - & - \\
\hline 18 & - & - & \\
\hline 19 & - & - & - \\
\hline 20 & - & E coli & E coli \\
\hline 21 & E coli & Calbicans & - \\
\hline \multicolumn{4}{|c|}{ Group 2} \\
\hline 1 & - & Calbicans & Calbicans \\
\hline 2 & E coli & - & \\
\hline 3 & - & Enterococcus & - \\
\hline 4 & - & - & \\
\hline 5 & - & L bifidus & - \\
\hline 6 & - & E coli & \\
\hline 7 & - & - & \\
\hline 8 & - & $C$ albicans & C albicans \\
\hline 9 & - & Calbicans & - \\
\hline 10 & - & - & - \\
\hline 11 & - & - & - \\
\hline 12 & - & - & \\
\hline 13 & - & - & \\
\hline 14 & - & L bifidus & - \\
\hline 15 & E coli & - & E coli \\
\hline 16 & - & - & \\
\hline 17 & - & - & \\
\hline 18 & - & Enterococcus & - \\
\hline 19 & - & E coli & - \\
\hline
\end{tabular}

-, No bacterial colonisation $>10^{5} / 0.5 \mathrm{ml}$ aspirate. 

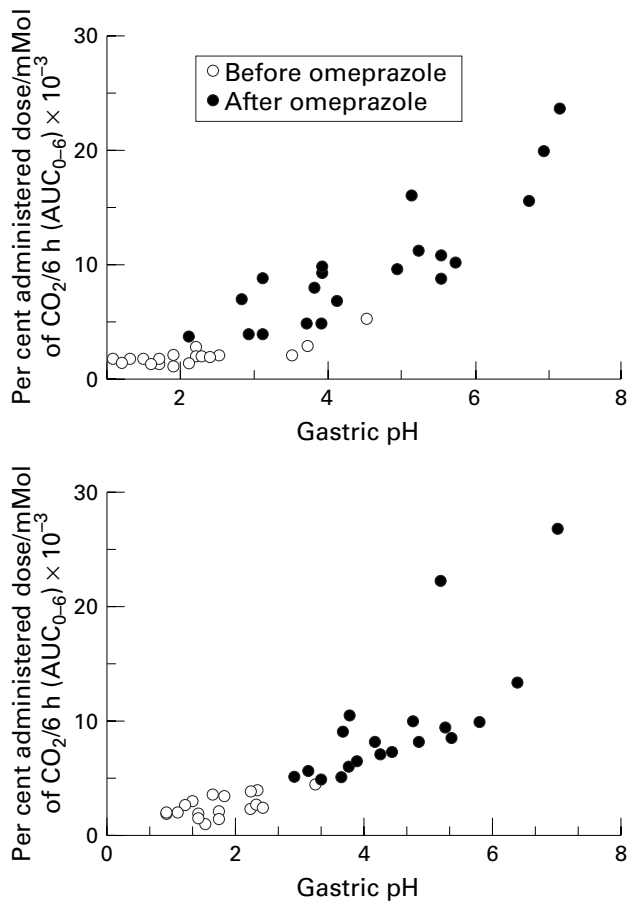

Figure 1 Correlation of gastric $p H$ and $A U C_{0-6}$ before and after omeprazole treatment in groups 1 (upper panel) and 2 (lower panel).

GASTRIC $\mathrm{pH}$

Before omeprazole treatment, the mean values of gastric $\mathrm{pH}$ in groups 1 and 2, respectively, were $2.17(0.90)$ and $1.73(0.59)$. After omeprazole treatment, the corresponding values were $4.42(1.45)$ and $4.44(1.10)$. There were significant differences in gastric $\mathrm{pH}$ before and after omeprazole treatment in both groups (paired Student's $t$ test, $\mathrm{p}<0.05$ ). Figure 1 presents the correlations between $\mathrm{AUC}_{0-6}$ and gastric $\mathrm{pH}$ in both groups. $\mathrm{AUC}_{0-6}$ was significantly correlated with gastric $\mathrm{pH}$ both before and after omeprazole treatment in the two groups $\left(r^{2}=0.570\right.$ and 0.755 , respectively, in

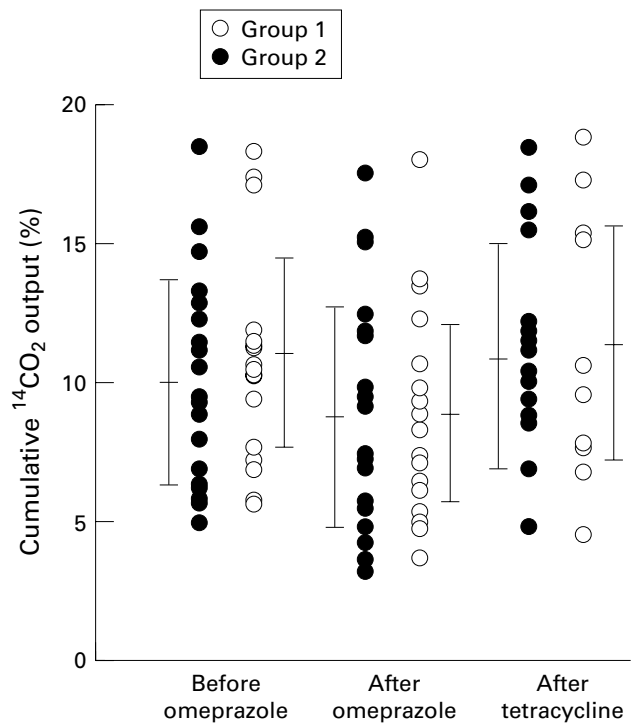

Figure $2{ }^{14} \mathrm{C}$ triolein breath test. Breath cumulative output of ${ }^{14} \mathrm{CO}_{2}(\%$ administered dose $/ 6 \mathrm{~h}$ ) after ingestion of $5 \mu \mathrm{Ci}$ of ${ }^{14} \mathrm{C}$ triolein in $30 \mathrm{ml}$ of Lipomul. All data indicate mean values with $1 S D$ error bars. group $1(\mathrm{n}=21)$ and $r^{2}=0.380$ and 0.550 in group $2(\mathrm{n}=19) ; \mathrm{p}<0.05)$.

${ }^{14} \mathrm{C}$ TRIOLEIN BREATH TEST

In group 1, the cumulative ${ }^{14} \mathrm{CO}_{2}$ output per six hours was $10.21(3.62) \%, 8.70(4.08) \%$, and $11.18(3.97) \%$ of the administered dose before and after omeprazole treatment, and after tetracycline treatment, respectively.

In group 2, the cumulative ${ }^{14} \mathrm{CO}_{2}$ output per six hours was 10.72 (3.72)\%, $8.61(3.78) \%$, and $11.41(4.48) \%$ of the administered dose before and after omeprazole treatment, and after tetracycline treatment, respectively.

After omeprazole treatment, both groups had significantly lower cumulative six hour ${ }^{14} \mathrm{CO}_{2}$ outputs, consistent with impaired fat absorption $(\mathrm{p}<0.05$, paired $t$ test). There was no significant difference between the two groups (fig 2).

\section{Discussion}

Our data show bacterial overgrowth in the stomach and jejunum of patients with gastric ulcer and in healthy volunteers after treatment with omeprazole. These bacteria alter the metabolism of bile acids and induce fat malabsorption, as evidenced by increased ${ }^{14} \mathrm{CO}_{2}$ output after the administration of glycine $-1-{ }^{14} \mathrm{C}$ labelled glycocholate and decreased ${ }^{14} \mathrm{CO}_{2}$ output after the administration of ${ }^{14} \mathrm{C}$ triolein. Most of the observed species of bacteria had deconjugation capability. The bacterial overgrowth appeared to be associated with an omeprazole induced shift to neutral $\mathrm{pH}$ in the gastric juice. There were no significant differences in gastric $\mathrm{pH}$ or $\mathrm{AUC}_{0-6}$ between the two groups.

An increase in deconjugation of bile acids due to bacterial overgrowth in the upper small intestine has been shown in patients with several diseases using a breath analysis technique based on glycine- $1-{ }^{14} \mathrm{C}$ labelled glycocholate. Increased deconjugation is detected by an increase in the excretion of ${ }^{14} \mathrm{CO}_{2}$ in expired air and an early rise in ${ }^{14} \mathrm{CO}_{2}$ output. ${ }^{16}{ }^{17}$ Possible and classic causes of bacterial overgrowth include blind loop syndrome and ileal bypass, which cause stasis of jejunal fluid, and anatomic abnormalities of the intestine, which permit rapid bacterial overgrowth. ${ }^{16}{ }^{17}$ Pharmacologically, omeprazole induced hypochlorhydria produces periods during the day in which the gastric juice is at or near a neutral $\mathrm{pH}$ when omeprazole is given once daily. ${ }^{11}$ The findings of the present study showed that hypochlorhydria not only was clearly sufficient to induce major changes in the gastric flora, but also affected the $\mathrm{pH}$ of the jejunal fluid sufficiently to allow bacterial overgrowth in the jejunum. Several published studies have examined the influence of gastric $\mathrm{pH}$ on bacterial growth in the jejunum and the source of bacterial overgrowth in the jejunum. Gastric juice $\mathrm{pH}$ has been reported to be an important factor influencing bacterial growth in the small intestine; gastric and jejunal contents of patients with partial gastrectomy, gastroenterostomy, or pernicious anaemia permitted significant growth of coliform bacilli. ${ }^{26}$ The effect of 
gastric hypochlorhydria on the distribution of bacteria in the intestines could be sufficiently predicted from these results. ${ }^{27}$

The number of bacteria passing from the stomach to the small intestine undoubtedly increases during hypochlorhydria. In a study using long tube aspiration in 19 healthy volunteers, ${ }^{28}$ the small bowel microflora was found to consist of small numbers of streptococci, lactobacilli, staphylococci, and fungi. In addition, the most common bacteria in the distal ileum (the anaerobes Bacteroides, Eubacterium, and Corynebacterium) were detected in these samples. ${ }^{28}$ We also found these anaerobic species in our jejunal fluid samples (table 1). Our results suggest therefore that the bacterial overgrowth in the jejunum contains anaerobes from the distal ileum as well as bacteria passing from the stomach (table 2), although the possibility is not ruled out that overgrowth of bacteria naturally living in the jejunum also occurs. Interestingly, the omeprazole induced shift to a more neutral $\mathrm{pH}$ in the gastric juice may promote the migration and growth of anaerobes from the distal ileum.

Regarding the site of deconjugation, it has been reported that after omeprazole administration, bacterial colonisation increases in the gastric juice. ${ }^{11}$ Some of these bacteria may exhibit deconjugation capability. In the present study, we did not determine whether the stomach or the jejunum was the site of deconjugation of orally administered glycine- $1-{ }^{14} \mathrm{C}$ labelled glycocholate. We cannot rule out the possibility that the deconjugation detected in the breath test took place, at least in part, in the stomach before the passage of bile acids into the jejunum, because $L$ bifidus and enterococcus with deconjugation capability were detected in the gastric juice. Due to the fact that several anaerobes with deconjugation capability were also present in the jejunal fluid however, it is conceivable that at least some deconjugation occurred in the jejunum as well as in the stomach. It is possible therefore that conjugated bile acids in human bile are deconjugated by bacterial species that have overgrown in the jejunum of individuals with increased gastric $\mathrm{pH}$.

The possibility of adverse effects after long term treatment with omeprazole has not been explored thoroughly, although a few adverse effects have been reported in clinical trials since $1983 .^{729}{ }^{30}$ We have shown significant fat malabsorption induced by omeprazole in the present study. Saltzman et al reported that elderly subjects with bacterial overgrowth and hypochlorhydria induced by omeprazole did not exhibit fat malabsorption. ${ }^{31}$ The method for detecting fat absorption was different from that used in the present study, which may explain the different results. Judging from our data, bacterial overgrowth in the jejunum causes fat malabsorption via increased deconjugation of bile acids even in the absence of a blind loop. ${ }^{32}$

We previously reported that cimetidine, an $\mathrm{H}_{2}$ receptor antagonist, induced bacterial overgrowth in the jejunum of healthy subjects, which promoted deconjugation of bile acid. ${ }^{334}$
Patients with gastric ulcer and healthy volunteers treated with omeprazole had slightly higher mean cumulative specific activity than healthy volunteers treated with cimetidine. Although this difference was not significant, the higher degree of deconjugation following omeprazole treatment may be explained by the greater reduction in intragastric acidity with omeprazole than with cimetidine ${ }^{35}$ and the increased incidence of gastric and duodenal bacterial overgrowth in patients treated with omeprazole versus cimetidine. ${ }^{36}$ Similarly, fat malabsorption may differ, as shown in the present study.

In addition, the mean value in cirrhotic patients with positive breath tests was reported as $18.70(6.01) \%$, with a mean gastric $\mathrm{pH}$ of $6.74(0.39) .^{37}$ The cirrhotic patients also had fat malabsorption. There was a close relation between mean cumulative specific activity and gastric $\mathrm{pH}$; this may be of clinical significance. Deconjugation of bile acids by bacterial overgrowth in the jejunum may lead to fat malabsorption, and this should be taken into account when long term treatment with omeprazole is being considered.

Omeprazole induced bacterial overgrowth has been shown in the upper small intestine in humans. ${ }^{32}{ }^{38-40}$ These data were, however, fragmentary and inconclusive. In addition, insufficient evidence has been obtained concerning increased deconjugation during treatment with omeprazole. Additional questions involve the identification of bacteria that overgrow in the jejunum, the deconjugation capability of these bacteria, simultaneous examination and direct comparison of the gastric and jejunal flora, and whether subjects with a positive bile acid breath test exhibit fat malabsorption. This is the first study to investigate these questions.

In summary, we have confirmed that after long term treatment with omeprazole, patients with gastric ulcer as well as healthy volunteers show increased deconjugation of bile acids and fat malabsorption caused by bacterial overgrowth in the jejunum. The bacterial overgrowth is composed of both anaerobes and aerobes with deconjugation capability and is promoted by omeprazole induced sustained hypochlorhydria in the gastric juice.

The authors gratefully acknowledge the review of this manuscript by Dr M Tanaka and Miss E I R Bryan.

1 Snepar R, Popolad GA, Romano R, Kobasa WD, Kaye D. Effect of cimetidine and antacid on gastric microbial flora. Infect Immun 1982;36:518-24

2 Du Moulin GC, Paterson DG, Hedley-Whyte J, Lisbon J. Aspiration of gastric bacteria in antacid-treated patients: a frequent cause of postoperative colonisation of the airway. Lancet 1982;i:242-5.

3 Ruddell WSJ, Axon ATR, Findlay JM, Bartholomew BA, Hill MJ. Effect of cimetidine on the gastric bacterial flora. Lancet 1980;i:672-4

4 Milton-Thompson GJ, Lightfoot NF, Ahmet Z, et al. Intragastric acidity, bacteria, nitrite, and $\mathrm{N}$-nitroso compounds before, during, and after cimetidine treatment. Lancet 1982;i:1091-5.

5 Molgora M, Basiliso G, Bozzani A, Camboni G, Bianchi PA. Intragastric and intraoesophageal $\mathrm{pH}$ monitoring in duodenal ulcer patients: effect of the new histamine duodenal un panist ramixotidine. Eur 7 Clin Pharmacol 1989;37:405-7.

6 Sharma BK, Santana IA, Wood EC, et al. Intragastric bacterial activity and nitrosation before, during, and after treatrial activity and nitrosation before, during, and af
ment with omeprazole. BMF 1984;289:717-9.

7 Maton P. Omeprazole. N Engl f Med 1991;423:965-75. 
8 Verdu E, Viani F, Armstrong D, et al. Effect of omeprazole on intragastric bacterial counts, nitrates, nitrites, and on intragastric bacterial counts, nitrates,

9 Husebye E, Skar V, Hoverstad T, Melby K. Fasting hypochlorhydria with Gram positive flora is highly prevalent in healthy old people. Gut 1992;33:1331-7.

10 Saltzman J. Epidemiology and natural history of atrophic gastritis. In: Holt P, Russell R, eds. Chronic gastritis and hypochlorhydria in the elderly. Boca Raton: CRC, 1993;31-47.

11 Walt RP, M de Gomes FA, Word EC, Logan LH, Pounder RE. Effect of daily oral omeprazole on 24 hour intragastric acidity. BMf 1983;287:12-14

12 Lind T, Cederberg C, Ekenved G, Haglund U, Olbe L. Effect of omeprazole - a gastric proton pump inhibitor-on pentagastrin stimulated acid secretion in man. Gut 1983;24:270-6.

13 Konturek SJ, Kweicien N, Obtulowicz W, Kopp B, Oleksy J Action of omeprazole (a benzimidazole derivative) on secretory responses to sham feeding and pentagastrin upon gastrin and pancreatic polypeptide in duodenal ulcer gastrin and pancreatic polyp

14 Londong W, Londong V, Cederberg C, Steffen H Dose-response study of omeprazole on meal-stimulated gastric secretion and gastrin release. Gastroenterology 1983; 85:1373-8.

15 Shindo K, Fukushima K. Deconjugation of bile acids by human intestinal bacteria. Gastroenterol fpn 1976;11: 167-74.

16 Sherr HP, Sasaki Y, Newman A, Banwell GJ, Wagner NH, Hendrix RT. Detection of bacterial deconjugation of bile salts by a convenient breath analysis technique. $N \mathrm{Engl} f$ Med 1971;285:656-61.

17 Fromm H, Hofmann AF. Breath test for altered bile-acid metabolism. Lancet 1971;ii:621-5.

18 Newcomer AD, Hofmann AF, DiMagno EP, Thomas PJ, Carlson GL. Triolein breath test: a sensitive and specific test for fat malabsorption. Gastroenterology 1979;76:6-13.

19 Chapman TJ, Maltby P, Stockdale HR, King D, Smith ML. The ${ }^{14} \mathrm{C}$ triolein breath test-technique, normal data and The ${ }^{14}$ C triolein breath test-technique, normal data and

20 M'Koma AE, Lindquist K, Liljeqvist L. Biochemical laboratory data in patients before and after restorative proctocolectomy. A study on 83 patients with a follow-up of 36 months. Ann Chir 1994;48:525-34.

21 King D, Smith ML, Chapman TJ, Stockdale HR, Lye M. Fat malabsorption in elderly patients with cardiac cachexia. Age Ageing 1996;25:144-9.

22 Bergey DH. Bergey's manual of determinative bacteriology. Vol 1. 1st edn. Baltimore: Williams and Wilkins, 1984 561-604

23 Drasar BS, Crowther JS. The cultivation of human intestinal bacteria. In: Shapton DA, Board RG, eds. Isolation of anaerobes. Society for Applied Bacteriology, Technical Series no. 5. London and New York: Academic Press, 1971:93-7.
24 Eneroth P, Jovall JS. Extraction, purification, and chromatographic analysis of bile acids in biological materials. In: Nair PP, Kritchevsky D, eds. The bile acids. Vol 1. New York: Plenum Press, 1971:121-71.

25 Hofmann AF. Thin layer adsorption chromatography of free and conjugated bile acids on silicic acid. F Lipid Res 1962; 3:127-32.

26 Allan GJD, Shiner M. Influence of gastric $\mathrm{pH}$ on gastric and jejunal flora. Gut 1967;8:574-81.

27 Drasar BS, Shiner M, McLeod GM. Studies on the intestinal flora of the gastrointestinal tract in healthy and achlorhydric persons. Gastroenterology 1969;56:71-9.

28 Gorbach SL, Nahas L, Lerner PJ. Studies of intestinal microflora. Gastroenterology 1967;53:856-67.

29 Arnold R, Koop H. Omeprazole: long-term safety. Digestion 1989;44(suppl 1):77-86.

30 Solvell L. The clinical safety of omeprazole. Scand $\mathcal{F}$ Gastroenterol 1989;166(suppl):106-10.

31 Saltzman JR, Kowdley KV, Pedrosa MC, et al. Bacterial overgrowth without clinical malabsorption in elderly hypochlorhydric subjects. Gastroenterology 1994;106: 615-23.

32 Shindo K, Yamazaki R, Mizuno T, Shionoiri H, Sugiyama $M$. Deconjugation ability of bacteria isolated from the jejunal fluids in the blind loop syndrome with ${ }^{14} \mathrm{CO}_{2}$ excretion, using the breath analysis technique and thin layer chromatography. Life Sci 1989;45:2275-83.

33 Shindo K, Fukumura $\mathrm{M}$. Effect of $\mathrm{H}_{2}$-receptor antagonists on bile acid metabolism. F Investig Med 1995;43:170-7.

34 Shindo K, Yamazaki R, Koide K, Fukumura M, Hirai Y. Alteration of bile acid metabolism by cimetidine in healthy humans. F Investig Med 1996;44:462-9.

35 Viani F, Idstrom JP, Emde C, et al. Does omeprazole cause gastric anacidity in healthy subjects? Gastroenterology 1992; 100:873-7.

36 Thorens J, Froehlich F, Schwizer W, et al. Bacterial overgrowth during treatment with omeprazole compared with cimetidine: a prospective randomised double blind study. Gut 1996;39:54-9.

37 Shindo K, Machida M, Miyakawa K, Fukumura M. A syndrome of cirrhosis, achlorhydria, small intestinal bacterial overgowth, and fat malabsorption. Am $\mathcal{f}$ Gastroenterol 1993;88:2084-91.

38 Fried M, Siegrist H, Frei R, et al. Duodenal bacterial overgrowth during treatment in outpatients with omeprazole. Gut $1994 ; 35: 23-6$.

39 Gough A, Andrews D, Bacon PA, Emery P. Evidence of omeprazole-induced small bowel bacterial overgrowth in patients with scleroderma. Br F Rheumatol 1995;34:976-7.

40 Camilo E, Zimmerman J, Mason JB, et al. Folate synthesized by bacteria in the human upper small intestine is assimilated by the host. Gastroenterology 1996;110:991-8. 